\title{
Pengaruh Price To Book Value (PBV), Debt To Equity Ratio (DER), Return on Assets (ROA) Terhadap Price Earning Ratio (PER) pada Perusahaan Sub Sektor Plastik dan Kemasan Yang Terdaftar di Bursa Efek Indonesia
}

\author{
Marissa Putriana \\ Fakultas Ekonomi, Universitas Batanghari Jambi, Indonesia \\ Correspondence email: marissa.putriana89@gmail.com
}

\begin{abstract}
This research aims to obtain empirical evidence regarding the influence of Price to Book Value (PBV), Debt to Equity Ratio(DER), Return on assets (ROA) against the Price Earning Ratio. (PER) The data used are secondary data in the form of the financial statements the company sub sectors of plastics and packaging listed in indonesia stock exchange period 2015-2017. The sample used as 6 companies, withdrawing a sample using the method of purposive sampling. Analytical techniques used was multiple linear regression. The results showed that (1) the Price to Book Value, Debt to Equity Ratio, Return on assets simultaneously effect significantly to Price Earning Ratio (2) Price to Book Value and Return on assets partially effect significantly to Price Earning Ratio, while Debt to Equity Ratio partially do not affect significantly to Price Earning Ratio. Based on results of testing the coefficient of determination $R$ square value was known to 0.703. Meaning of 70.3\% Price Earning Ratio variable can be explained by Price to Book Value, Debt to Equity Ratio and Return on assets, while the remaining $29.7 \%$ are affected by other variables outside of this research.
\end{abstract}

Keywords : Price to Book Value, Debt to Equity Ratio, Return on Assets, Price Earning Ratio

\section{PENDAHULUAN}

Perkembangan pasar modal di Indonesia saat ini mengalami peningkatan yang cukup signifikan, ditandai dengan nilai kapitalisasi, pasar modal Indonesia tumbuh signifikan dari posisi Rp 2,73 milir pada 1877 menjadi Rp 6.870,7 triliun per 8 Agustus 2018 (Liputan6.com). Pasar modal merupakan tempat bertemunya pihak yang memiliki kelebihan dana dengan pihak yang membutuhkan dana untuk memperjual belikan sekuritas yang umumnya memiliki umur lebih dari satu tahun, seperti saham (Tandelilin, 2010). Semakin tinggi peminat akan investasi melalui pasar modal maka semakin dibutuhkannya pemahaman yang mendasar dalam menganalisis saham sebelum berinvestasi, agar investasi dapat memberikan keuntungan (return) yang diharapkan. Maka sebelum mengambil keputusan berinvestasi, tentu investor membutuhkan analisis yang mendalam untuk memilih saham dari berbagai perusahaan yang ada pada pasar modal. Informasi mengenai harga saham dan pergerakannya menjadi salah satu keputusan berinvestasi pada suatu perusahaan. Hayati (2010) mengemukakan ada dua macam analisis yang banyak digunakan untuk menentukan nilai sebenarnya dari saham yakni dengan menggunakan analisis sekuritas fundamental (fundamental security analysis) atau analisis perusahaan (company analysis) dan analisa teknis (technical analysis). Analisis fundamental menggunakan data fundamental, yaitu data yang berasal dari keuangan perusahaan sedangkan analisis teknis menggunakan data pasar dari nilai saham untuk menentukan nilai dari saham. (Adisetiawan, 2018).

Analisis perusahaan bisa memberikan gambaran kepada investor tentang nilai perusahaan, karakteristik internal perusahaan, kualitas perusahaan, kinerja manajemenn dan prospek perusahaan di masa mendatang. Cara memilih perusahaan dengan menggunakan data laporan keuangan adalah dengan membandingkan antara beberapa perusahaan dalam industri yang sama. Investor dapat membandingkan angka penjualan, laba bersih atau pertumbuhan diantara perusahaan dengan menggunakan rasio. Price Earning Ratio (PER) sebagai salah satu ukuran dasar dalam analisis fundamental saham, walau pun Price Earning Ratio bukan satu-satunya penilaian yang dipertimbangkan dalam memutuskan pilihan dalam berinvestasi saham, rasio ini dapat menunjukkan bagaimana pasar menghargai kinerja perusahaan yang dicerminkan oleh Earning per share nya. Price Earning Ratio menunjukkan hubungan antara pasar saham biasa dengan Earning per share. Makin besar Price Earning Ratio suatu saham maka harga saham tersebut akan semakin mahal terhadap pendapatan bersih per sahamnya. Angka rasio ini biasanya digunakan investor 
untuk memprediksi kemampuan perusahaan dalam menghasilkan laba dimasa yang akan datang (Prastowo, 2002).

Price Earning Ratio memiliki beberapa atribut menarik yaitu memberikan standar yang baik dalam membandingkan harga saham untuk laba per lembar saham yang berbeda dan kemudahan dalam membuat perkiraan yang digunakan sebagai input pada $\mathrm{P} / \mathrm{E}$ rasio model, serta memudahkan atau membantu judgement dalam menganalisis. Oleh karena model PER lebih sering digunakan dalam penilaian saham, maka menentukan faktor-faktor apakah yang mempengaruhi PER dengan mengetahui seberapa jauh faktor-faktor tersebut mempengaruhi PER adalah sangat penting (Utomo, 2016). Dalam penelitian ini dipilih variabel independen yang mempengaruhi Price Earning Ratio yaitu Price to Book Value (PBV), Debt to Eqituy Ratio (DER), Return on Assets (ROA). Pemilihan didasarkan pada hasil penelitian terdahulu yang dilakukan Hayati (2010) yang menghasilkan Price to Book Value tidak berpengaruh signifikan terhadap PER sedangkan ROA berpengaruh signifikan terhadap PER. Penelitian Septadi (2013) dan Yusuf (2014) menghasilkan ROA berpengaruh positif signifikan terhadap PER. Utomo (2016) menghasilkan DER tidak berpengaruh signifikan terhadap PER sedangkan PBV berpengaruh signifikan terhadap PER, Frengky (2018) dalam penelitiannya menghasilkan DER berpengaruh negatif signifikan terhadap PER sedangkan ROA tidak berpengaruh signifikan terhadap PER. (Adisetiawan, 2017)

Rasio harga pasar atas nilai buku (Price to Book Value) merupakan "pembagian harga pasar per lembar saham dengan nilai buku per lembar saham. Rasio ini membandingkan nilai pasar investasi pada perusahaan dengan biayanya. Nilai yang lebih kecil dari 1 berarti bahwa perusahan gagal menciptakan nilai bagi pemegang sahamnya"(Rahardjo, 2009). Debt to Equity Ratio (DER) merupakan rasio yang digunakan untuk menilai utang dengan ekuitas. Rasio ini dicari dengan cara membandingkan antara seluruh utang, termasuk utang lancar dengan seluruh ekuitas (Kasmir, 2011). Menurut Brigham et al dalam Fahmi (2014) Debt to Equity Ratio adalah Ukuran yang dipakai dalam menganalisis laporan keuangan untuk memperlihatkan besarnya jaminan yang tersedia untuk kreditor. Semakin rendah rasio ini semakin baik karena aman bagi kreditor saat likuidasi. Sudut pandang investor, salah satu indikator penting untuk menilai prospek perusahaan di masa yang akan datang dengan melihat sejauh mana pertumbuhan profitabilitas perusahaan, salah satunya adalah Return on Asset (ROA). Indikator ini sangat penting diperhatikan untuk mengetahui sejauh mana aktiva yang dimiliki perusahaan dapat menghasilkan laba yang nantinya akan mempengaruhi pergerakan harga saham (Tendeilin,2010). Menurut Brigham (2006), nilai ROA yang semakin tinggi menunjukkan suatu perusahaan semakin efisien dalam memanfaatkan asetnya untuk memperoleh laba, sehingga nilai perusahaan meningkat.

Penelitian ini dilakukan pada perusahaan sub sektor plastik dan kemasan yang terdaftar di Bursa Efek Indonesia periode 2015-2017. Industri kemasan plastik berperan penting dalam rantai pasok bagi sektor strategis lainnya seperti industri makanan dan minuman, farmasi, kosmetik, serta elektronika. Berdasarkan Recana Induk Pembangunan Industri Nasional (RIPIN), Kementrian Perindustrian menetapkan industri plastik hilir sebagai sektor prioritas pengembangan pada tahun 2015-2019 (Siaran Pers, website kemenperin.go.id). Dikarenakan memiliki peran terhadap sektor lain, tentunya pertumbuhan industri plastik dan kemasan dipengaruhi pertumbuhan industri strategis lainnya tersebut. Jika ada salah satu atau pun beberapa dari sektor lainnya tersebut mengalami penurunan penjualan maka akan berdampak pula terhadap penurunan permintaan akan produk industri plastik dan kemasan. Industri plastik dan kemasan juga dihadapkan pada isu lingkungan karena sifat bahan plastik yang sulit untuk diuraikan yang bisa berdampak terhadap lingkungan untuk jangka panjang, isu tersebut tentu menjadi kendala bagi industri plastik dan kemasan dalam meningkatkan pertumbuhan dan keberlangsungan usahanya. Berdasarkan uraian diatas, maka hipotesis dalam penelitian ini adalah diduga Price to Book Value (PBV), Debt to Equity Ratio (DER), dan Return on Assets (ROA) secara simultan berpengaruh signifikan terhadap Price Earning Ratio (PER) pada Perusahaan Sub Sektor Plastik dan Kemasan yang Terdaftar di Bursa Efek Indonesia periode 2015 2017.

\section{METODE PENELITIAN}

Populasi yang digunakan dalam penelitian ini adalah sub sektor plastik dan kertas yang terdaftar di Bursa Efek Indonesia (BEI). Pengambilan sampel dilakukan dengan metode purposive sampling atau 
penarikan sampel menggunakan kriteria tertentu. Adapun kriteria sampel yakni perusahaan sub sektor plastik dan kemasan yang terdaftar di Bursa efek selama tahun 2015-2017, memiliki laporan keuangan yang lengkap, memiliki nilai yang positif dari variabel -variabel yang diteliti. Berdasarkan kriteria tersebut didapat sampel sebanyak 6 perusahaan dengan tahun pengamatan 2015 sampai 2017. Jenis data yang digunakan adalah data sekunder yaitu data yang diolah lebih lanjut dan telah disajikan oleh pihak lain, misalnya dalam bentuk tabel-tabel atau diagram-diagram, (Hariwijaya, 2008), adapun data sekunder dalam penelitian ini berupa laporan keuangan yang diterbitkan oleh perusahaan sub sektor plastik dan kemasan. Metode pengumpulan data yang digunakan dalam penelitian ini adalah Penelitian Pustaka (Library Research). Metode analisis data yang digunakan adalah teknik regresi linear berganda. Model yang digunakan adalah sebagai berikut:

$\mathrm{Y}=\alpha+\beta_{1} \mathrm{X}_{1}+\beta_{2} \mathrm{X}_{2}+\beta_{3} \mathrm{X}_{3}+\mathrm{e}$

Dimana: $\mathrm{Y}=$ Price Earning Ratio $(\mathrm{PER}) ; \alpha=$ Konstanta; $\beta_{1,2,3} \quad=$ Koefisien regresi; $\mathrm{X}_{1}=$ Price to Book Value (PBV); $\mathrm{X}_{2}=$ Debt to Equity Ratio (DER); $\mathrm{X}_{3}=$ Return on Assets $(\mathrm{ROA}) ; \mathrm{e}=$ error

\section{HASIL DAN PEMBAHASAN}

\section{Uji Asumsi Klasik}

Uji Normalitas

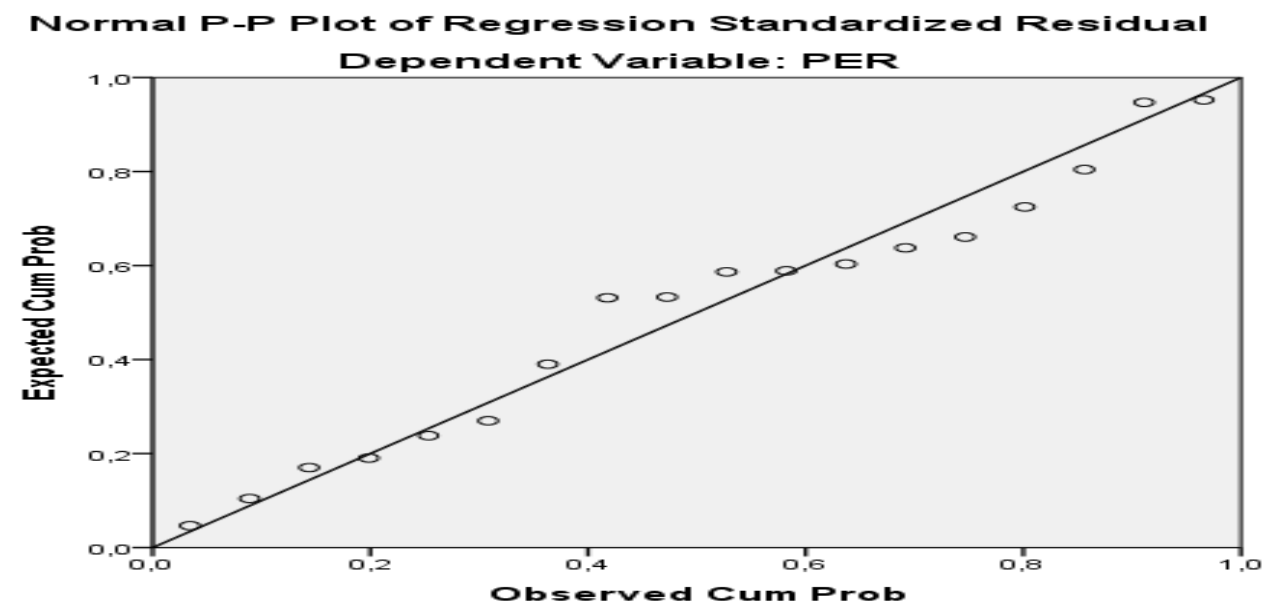

\section{Gambar 1 \\ P-Plot}

Berdasarkan gambar 1 hasil Uji Normalitas P-Plot di atas menunjukkan bahwa titik-titik menyebar di sekitar garis diagonal dan mengikuti arah garis diagonal maka disimpulkan data berdistribusi normal.

\section{Uji Multikolinearitas}

Berdasarkan Tabel 1 di bawah, dapat dilihat bahwa nilai Tolerance dan VIF menunjukkan tidak ada satupun variabel independent yang memiliki nilai Tolerance yang kurang dari 0,1 dan tidak memiliki nilai VIF yang lebih besar dari 10. Maka disimpukan bahwa tidak terjadi multikolinearitas antar variabel independen.

Tabel 1

Coefficients $^{\mathrm{a}}$

\begin{tabular}{|ll|r|r|}
\hline \multirow{2}{*}{ Model } & \multicolumn{2}{|c|}{ Collinearity Statistics } \\
\cline { 3 - 4 } & (Constant) & Tolerance & \multicolumn{1}{|c|}{ VIF } \\
\hline 1 & PBV & & 1,068 \\
& DER &, 595 & 1,680 \\
& ROA &, 568 & 1,760 \\
\hline
\end{tabular}

Sumber: data olahan 


\section{Uji Heteroskedastisitas}

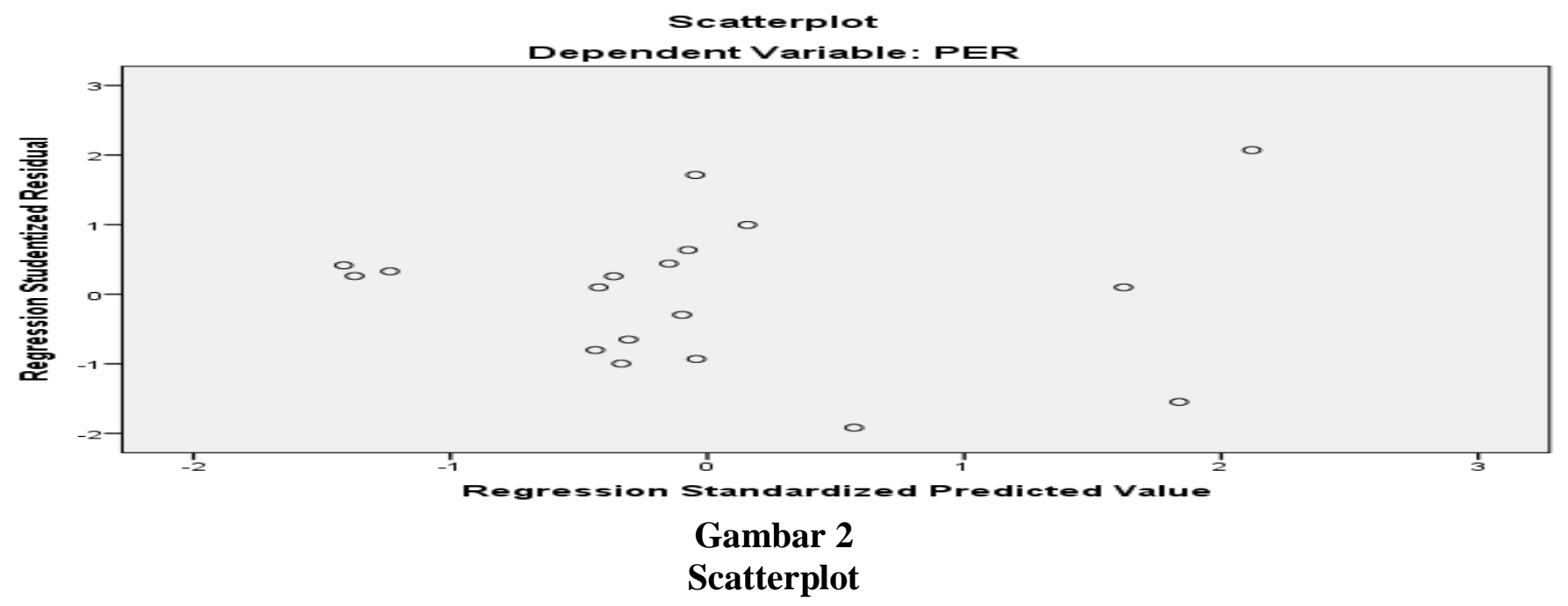

Berdasarkan gambar 2 grafik scatterplot di atas menunjukkan bahwa titik-titik menyebar secara acak, tidak membentuk sebuah pola yang teratur dan menyebar baik di atas maupun di bawah angka 0 pada sumbu Y, dengan demikian dapat disimpulkan tidak terjadi heteroskedastisitas pada model regresi ini.

\section{Uji Autokorelasi}

Hasil uji autokorelasi ditunjukkan dengan tabel 2 run test di bawah menunjukkan bahwa nilai Asymp. Sig. (2-tailed) > 0,05 yaitu senilai 1,000 yang berarti tidak terdapat masalah autokorelasi.

Tabel 2

Run Test

\begin{tabular}{|c|c|}
\hline \multicolumn{2}{|c|}{ Run Test } \\
\hline & \\
\hline Test Value $^{\mathrm{a}}$ & 1,93378 \\
\hline Cases < Test Value & 9 \\
\hline Cases $>=$ Test Value & 9 \\
\hline Total Cases & 18 \\
\hline Number of Runs & 10 \\
\hline $\mathrm{Z}$ &, 000 \\
\hline Asymp. Sig. (2-tailed) & 1,000 \\
\hline
\end{tabular}

Sumber: data olahan

\section{Analisis Regresi Linear Berganda}

Regresi linear berganda dilakukan untuk mengukur seberapa besar pengaruh variabel independen terhadap variabel dependen. Hasil persamaan regresi yang diolah dengan SPSS 22 dapat dilihat pada tabel 3 berikut :

Tabel 3

Analisis Regresi Linear Berganda

\begin{tabular}{|c|l|r|r|r|}
\hline \multirow{2}{*}{ Model } & \multicolumn{2}{|c|}{ Unstandardized Coefficients } & \multicolumn{2}{c|}{ Standardized Coefficients } \\
\cline { 2 - 5 } & (Constant) & & Std. Error & Beta \\
\hline 1 & PBV & 28,693 & 9,749 & -814 \\
\hline & DER & 12,685 & 2,345 &,- 165 \\
\hline & ROA & $-7,919$ & 9,057 &,- 579 \\
\hline
\end{tabular}

Sumber: data olahan 
Hasil pengelolaan data yang ditunjukkan tabel 3 di atas, maka didapatkan nilai-nilai koefisien tiap variabel dan nilai konstanta sehingga didapatkan persamaan regresi linear sebagai berikut :

$\mathrm{Y}=28,693+12,685 \mathrm{X}_{1}-7,919 \mathrm{X}_{2}-2,463 \mathrm{X}_{3} \quad+\mathrm{e}$

Berdasarkan persamaan tersebut maka hasil perhitungan regresi diperoleh nilai konstanta adalah 28,693. Ini berarti bila variabel PBV $\left(\mathrm{X}_{1}\right)$, DER $\left(\mathrm{X}_{2}\right)$ dan ROA $\left(\mathrm{X}_{3}\right)$ adalah nol maka nilai PER (Y) adalah sebesar 28,693. PBV $\left(\mathrm{X}_{1}\right)$ mempunyai koefisien positif 12,685. Hal ini menunjukkan jika PBV meningkat 1 $\%$ maka PER akan naik sebesar 12,685 kali, dengan asumsi variabel independent lain tetap, dan begitu pun sebaliknya. Nilai koefisien regresi variabel DER $\left(\mathrm{X}_{2}\right)$ adalah negatif 7,919 ini menunjukkan jika DER meningkat $1 \%$ maka PER akan turun sebesar 7,919 kali, dengan asumsi variabel independent lain tetap, dan begitu pun sebaliknya. ROA $\left(\mathrm{X}_{3}\right)$ mempunyai koefisien negaif 2,463. Hal ini menunjukkan jika ROA meningkat $1 \%$ maka PER akan turun sebesar 2,463 kali dengan asumsi variabel independent lain tetap, dan begitu pun sebaliknya.

\section{Pengujian Hipotesis}

Uji $\boldsymbol{F}$ dependent.

Uji F dilakukan untuk menguji pengaruh variabel independent secara simultan terhadap variabel

Tabel 4.

Uji Statistik F

\begin{tabular}{lllllll}
\hline Model & & Sum of Squares & df & Mean Square & F & Sig. \\
\hline 1 & Regression & 5474,233 & 3 & 1824,744 & 11,062 &, $001^{\mathrm{b}}$ \\
& Residual & 2309,452 & 14 & 164,961 & & \\
& Total & 7783,685 & 17 & & & \\
\hline
\end{tabular}

Sumber: data olahan

Hasil perhitungan uji simultan pada tabel 4 di atas diperoleh $\mathrm{F}$ hitung lebih besar dibanding $\mathrm{F}$ tabel yakni $(11,062>3,34)$ dan tingkat signifikansi 0,001 lebih besar dari 0,05 yang berarti Hipotesis pertama diterima yaitu secara simultan atau bersama-sama Price to Book Value, Debt to Equity Ratio dan Return on Assets berpengaruh signifikan terhadap Price Earning Ratio. Artinya pergerakan nilai Price Earning Ratio suatu perusahaan dapat dipengaruhi oleh Price to Book Value, Debt to Equity Ratio dan Return on Assets.

\section{Uji $t$}

Uji parsial t digunakan untuk mengetahui apakah model persamaan regresi telah signifikan untuk digunakan untuk mengukur pengaruh secara parsial antara variable bebas $\mathrm{PBV}\left(\mathrm{X}_{1}\right), D E R\left(\mathrm{X}_{2}\right)$ dan $R O A$ $\left(\mathrm{X}_{3}\right)$ terhadap PER $(\mathrm{Y})$. Hasil pengolahan data dengan menggunakan program SPSS versi 22 diperoleh hasil uji t dapat dilihat pada tabel 5 sebagai berikut:

Tabel 5

Uji Statistik t

\begin{tabular}{|c|c|c|c|c|c|c|}
\hline \multirow{2}{*}{\multicolumn{2}{|c|}{ Model }} & \multicolumn{2}{|c|}{ Unstandardized Coefficients } & \multirow{2}{*}{$\begin{array}{c}\text { Standardized Coefficients } \\
\text { Beta }\end{array}$} & \multirow[b]{2}{*}{$\mathrm{t}$} & \multirow[b]{2}{*}{ Sig. } \\
\hline & & $\mathrm{B}$ & Std. Error & & & \\
\hline & (Constant) & 28,693 & 9,749 & & 2,943 &, 011 \\
\hline 1 & PBV & 12,685 & 2,345 &, 814 & 5,409 &, 000 \\
\hline & DER & $-7,919$ & 9,057 &,- 165 &,- 874 & ,397 \\
\hline & ROA & $-2,463$ &, 822 &,- 579 & $-2,998$ &, 010 \\
\hline
\end{tabular}

Sumber: data olahan

Berdasarkan tabel di atas maka dapat diuraikan pembahasan sebagai berikut :

1) Pengaruh Price to Book Value (PBV) terhadap Price Earning Ratio (PER) 
Berdasarkan hasil analisis regresi diketahui Price to Book Value memiliki thitung sebesar 5,409 yang lebih besar nilainya dibanding $t_{\text {tabel }}$ sebesar 2,145 dan dengan probabilitas 0,000 yang lebih kecil dari 0,05 maka Hipotesis yang menyatakan secara parsial Price to Book Value berpengaruh signifikan terhadap Price Earning Ratio diterima. Artinya Price to Book Value berpengaruh signifikan terhadap Price Earning Ratio pada sub sektor plastik dan kemasan yang terdafatar di Bursa Efek Indonesia periode 2015-2017. Hasil penelitian ini sejalan dengan Utomo (2016) yaitu Price to Book Value berpengaruh signifikan terhadap Price Earning Ratio. Price to Book Value memiliki pengaruh positif dan signifikan terhadap Price Earning Ratio menujukkan bahwa semakin besar nilai Price to Book Value maka semakin tinggi Price Earning Ratio membuat semakin tinggi nilai perusahaan yang akan berpengaruh terhadap keputusan investor maupun calon investor untuk menanamkan dananya ke dalam perusahaan. Hasil penelitian bertolak belakang dengan penelitian Hayati (2010) yang mana Price to Book Value tidak berpengaruh signifikan Price Earning Ratio.

2) Pengaruh Debt to Equity Ratio (DER) terhadap Price Earning Ratio (PER)

Berdasarkan hasil analisis regresi diketahui DER memiliki thitung sebesar 0,874 yang lebih kecil nilainya dibanding $t_{\text {tabel }}$ sebesar 2,145. Memiliki probabilitas 0,397 yang lebih besar dari 0,05. Maka Hipotesis yang menyatakan Debt to Equity Ratio (DER) secara parsial berpengaruh signifikan terhadap PER ditolak. Artinya Debt to Equity Ratio secara parsial tidak berpengaruh signifikan terhadap Price Earning Ratio pada sub sektor plastik dan kemasan yang terdafatar di Bursa Efek Indonesia periode 2015-2017. Dalam teori, DER berhubungan negatif dengan PER, ketika DER naik maka PER turun, begitu pun sebaliknya. Pada hasil penelitian ini DER memiliki hubungan negatif terhadap PER namun tidak signifikan. Hasil penelitian berbeda diperoleh Hayati (2010) dan Frengky (2018) yang menyatakan bahwa terdapat pengaruh negatif dan signifikan DER terhadap PER. Debt to Equity Ratio mencerminkan struktur finansial perusahaan dan sekaligus menunjukkan resiko finansialnya. Pengelolaan hutang perlu menjadi perhatian perusahaan, dengan pengelolaan hutang yang baik membuat penggunaan investasi menjadi lebih efektif dan efisien untuk menghasilkan keuntungan. Sebab hutang merupakan investasi pihak ketiga. Walaupun hutang perusahaan itu tinggi tetapi dalam pengelolaannya dapat menghasilan keuntungan lebih baik, maka perusahaan akan mampu mengembalikan atau membayar hutangnya sesuai waktu yang ditentukan (Hayati, 2010).

3) Pengaruh Return on Assets (ROA) terhadap Price Earning Ratio (PER)

Berdasarkan hasil analisis regresi diketahui Return on Assets memiliki thitung sebesar 2,998 yang lebih besar nilainya dibanding $t_{\text {tabel }}$ sebesar 2,145 dengan probabilitas 0,010 yang lebih kecil dari 0,05. Maka hipotesis yang menyatakan secara parsial ROA berpengaruh signifikan terhadap PER diterima. Artinya Return on Assets secara parsial berpengaruh signifikan terhadap Price Earning Ratio pada sub sektor plastik dan kemasan yang terdafatar di Bursa Efek Indonesia periode 2015-2017. Namun dari hasil penelitian ROA memiliki pengaruh negatif signifkan terhadap Price Earning Ratio, yang berarti semakin besar Return on Assets maka Price Earning Ratio akan semakin menurun pada perusahaan sub sektor plastik dan kemasan yang terdaftar di bursa efek indonesia. Hasil penelitian sebelumnya yang dilakukan Yusuf (2014), Septadi (2013), dan Hayati (2010) menunjukkan adanya pengaruh positif signifikan Return on Assets terhadap Price Earning Ratio, artinya setiap ada kenaikan Return on Assets maka mengakibatkan Price Earning Ratio juga mengalami kenaikan. Return on Assets menunjukkan sejauh mana kemampuan akitva yang dimiliki perusahaan dapat menghasilkan laba.

\section{Koefisien Determinasi}

Tabel 6.

Koefisien Determinasi

\begin{tabular}{|l|r|r|r|}
\hline Model & \multicolumn{1}{|c|}{ R } & R Square & Adjusted R Square \\
\hline 1 &, $839^{\text {a }}$ &, 703 &, 640 \\
\hline
\end{tabular}


Berdasarkan hasil pengujian koefisien determinasi diketahui nilai $\mathrm{R}$ square pada tabel 6 di atas adalah 0,703 atau sama dengan 70,3\%. Artinya sebesar 70,3\% PER dapat dijelaskan oleh variabel PBV, DER dan ROA, sedangkan sisanya 29,7\% dipengaruhi oleh variabel lain di luar penelitian ini.

\section{SIMPULAN}

Berdasarkan tujuan penelitian dan pembahasan yang telah dipaparkan diatas, maka dapat ditarik kesimpulan sebagai berikut:

1. Secara simultan Price to Book Value, Debt to Equity Ratio dan Return on Assets berpengaruh signifikan terhadap Price Earning Ratio pada perusahaan sub sektor plastik dan kemasan yang terdaftar di bursa efek Indonesia periode 2015-2017.

2. Secara parsial Price to Book Value berpengaruh positif dan signifikan terhadap Price Earning Ratio pada perusahaan sub sektor plastik dan kemasan yang terdaftar di bursa efek Indonesia periode 20152017.

3. Debt to Equity Ratio secara parsial berpengaruh negatif tidak signifikan terhadap Price Earning Ratio pada perusahaan sub sektor plastik dan kemasan yang terdaftar di bursa efek Indonesia periode 20152017.

4. Return on Assets secara parsial berpengaruh negatif signifikan terhadap Price Earning Ratio pada perusahaan sub sektor plastik dan kemasan yang terdaftar di bursa efek Indonesia periode 2015-2017.

\section{DAFTAR PUSTAKA}

Adisetiawan, R., 2018, Does Stock Split Influence to Liquidity and Stock Return? (Empirical Evidence in the Indonesian Capital), Asian Economic and Financial Review, 8(5), 682-690

Adisetiawan, R., 2017, Globalisasi Pasar Modal Dunia dan Pengaruhnya Terhadap Pasar Modal Indonesia, Ekonomis: Journal of Ekonomics and Business, 1(1), 10-17

Brigham, Eugene F and Joel F.Houston, 2006. Dasar-Dasar Manajemen Keuangan, alih bahasa Ali Akbar Yulianto, Buku satu, Edisi sepuluh, PT. Salemba Empat, Jakarta.

Prastowo. Dwi., 2002, Analisis Laporan Keuangan, Cetakan Kedua, Yogyakarta: UPP AMP YKPN.

Fahmi, Irham. 2014. Analisis Laporan Keuangan. Cetakan keempat. Bandung: Penerbit CV. Alfabeta.

Frengky David Sijabat, Anak Agung Gede Suarjaya. 2018. Pengaruh DPR, DER, ROA dan ROE Terhadap Price Earning Ratio Pada Perusahaan Manufaktur. E-Jurnal Manajemen Unud, Vol. 7, No. 7: 36813708.

Hariwijaya, M. dan Triton P.B. (2008). Pedoman Penulisan Ilmiah Proposal dan Skripsi. Yogyakarta: Oryza.

Hayati, Nurul (2010). Faktor-faktor yang Mempengaruhi Price Earning Ratio sebagai Salah Satu Kriteria Keputusan Investasi Saham Perusahaan Real Estate dan Property di Bursa Efek Indonesia. Jurnal Manajemen dan Akuntansi, Vol. 11, No.1. pp 53-62.

Kasmir, 2011. Analisis Laporan Keuangan Catatan Keempat, PT. Raja Grafindo Persada, Jakarta.

Kementrian perindustrian, "Industri Kemasan Plastik Jadi Rantai Pasok Penting Sektor Lain". http://www.kemenperin.go.id/artikel/16971/Industri-Kemasan-Plastik-Jadi-Rantai-Pasok-PentingSektor-Lain (diakses 4 April 2019).

Liputan6, “ Melihat Perkembangan Pasar Modal Selama 41 Tahun". https://www.liputan6.com/bisnis/read/3615885/melihat-perkembangan-pasar-modal-ri-selama-41tahun (diakses 4 April 2019).

Rahardjo, Budi. 2009. Dasar-dasar Analisis Fundamental Saham Laporan Keuangan Perusahaan. Yogyakarta: Penerbit Gajah Mada University Press.

Septadi, Rizki Aditya et. al. 2013. Analisis Pengaruh Return on Asset (ROA), Return on Equity (ROE) dan Tingkat Inflasi Terhadap Price Earning Ratio Pada Perusahaan Manufaktur Bidang Food And Beverage Yang Terdaftar Pada Bursa Efek Indonesia Periode 2010-2011. Diponegoro Journal of Social and Politic Hlm 1-8. Jurusan Administrasi Bisnis. Fakultas Ilmu Sosial dan Ilmu Politik Universitas Diponegoro Semarang. 
Tandelilin, Eduardus. 2010. Portofolio dan Investasi: Teori dan Aplikasi. Edisi Pertama. Yogyakarta: Kanisius IKAPI.

Utomo, W., Andini, R., \& Raharjo, K. 2016. Pengaruh leverage (DER), Price book value (PBV), Ukuran Perusahaan (SIZE), return on equty (ROE), deviden payout ratio (DPR) dan likuiditas (CR) terhadap price earning ratio (PER) pada perusahaan manufaktur yang listing di BEI tahun 2009-2014. Journal Of Accounting, 2(2).

Yusuf. 2014. Pengaruh Return On Equity (ROE), Return On Assets (ROA) dan Net Interest Margin (NIM) terhadap Price Earning Ratio (PER) pada perusahaan perbankan di Bursa Efek Indonesia. Jurnal Neo-Bis. Volume 8 No 02.pp. 190-204. 